\title{
Relation between Students' Perception of Teaching Styles and Students' Academic Engagement in South Valley and

\author{
Assiut Universities
}

\author{
Hanaa Esmail Sabra1, Atyat Mohammed Hassan2, Heba Mostafa Mohammed 3 \\ 1Nursing Administration, Faculty of Nursing, South Valley University, Egypt \\ 2Pediatric and Premature Nursing, Faculty of Nursing, Assiut University, Egypt \\ 3Obstetrics \& Gynecological Nursing and Reproductive Health, Faculty of Nursing, Assiut University, Egypt
}

\begin{abstract}
Teaching styles play an important role in encouraging student engagement. Study aims: To determine the relationship between students' perceptions of teaching styles and students' academic engagement in South Valley and Assiut Universities. Study design: Descriptive correlational research design was used. Setting: The study was conducted at two Nursing Faculties in South Valley and Assiut Universities. Subjects: The study included 600 nursing students which chosen by a simple random sample. Tools: Two tools were used for data collection. Tool I was students' academic engagement questionnaire and tool II was teaching styles' questionnaire. Results: It was found that higher students' academic engagement (50.8\%) in Assiut University compared to $(49.2 \%)$ in South Valley University. Also, the most dominant teaching style was democratic teaching style with statistically significant differences $(\mathrm{P}=0.02,0.000,0.000)$ respectively as regard administration, pediatric and obstetric \& gynecological nursing and reproductive health departments in South Valley and Assiut Universities. Moreover, there was a positive statistically significant difference between teaching styles and students' academic engagement as regard democratic teaching style in the pediatric nursing department in Assiut and South Valley Universities $(\mathrm{P}=0.000,0.01)$ respectively and obstetric \& gynecological nursing and reproductive Health departments in South Valley University $(\mathrm{P}=0.01)$. Conclusion: Students' academic engagement in Assiut University was higher than South Valley University. The most dominant teaching styles in South Valley and Assiut universities were democratically followed by authoritarian. Also, there was a statistically significant difference between students' perception of teaching styles and their academic engagement. Recommendation: The university and the lecturers should provide a positive teaching and learning environment which is up to date because it can form a conducive and suitable environment for students' academic engagement.
\end{abstract}

\begin{tabular}{ll}
\hline Key words: Students' perceptions, teaching styles, students' academic engagement. \\
\hline Introduction & $\begin{array}{l}\text { because the student's capability and } \\
\text { preparedness to learn firstly depending on } \\
\text { availability of teacher's teaching style does }\end{array}$ \\
Student academic excellence is the & $\begin{array}{l}\text { not only concerning to the students } \\
\text { themselves. (Abdull et al., 2014). Also, }\end{array}$ \\
main agenda of any educational institutions & Casuso et al., (2013) illustrated that the \\
and colleges. It requires action and & encouraging student engagement consider an \\
cooperation from all parties for achieving. & fundamental role of an educational \\
The environment of learning must be &
\end{tabular}


institutions, if this factor is involved in student enhancing the success point and followed.

Students' academic engagement: "It is defined as the students' psychological investment in and the effort directed toward learning, understanding and mastering knowledge, skills, or crafts that academic work intends to promote" (Shaari et al., 2014). Also, it is a complex term that emphasizes students' various patterns in motivation, mental process and behavior. It is a measure or signal that joint theoretical or academic recognition (which suggest to gain along with teachers, meet or find a concern in the event regarding behaviors) and academic participation (which restrain the learner's effort, including hours used up or consumed on homework assignment, encounter deadlines, not skipping classes, and so on) (Al-Hendawi, 2012).

Engagement is an important or an eminent academic orientation that accepts pig and expanded attention of learners and researchers. Engagement as a passage to better unfriendliness, to turn away learner dullness and dissatisfaction, to increase students' encouragement, push, and involvement in college regarding performance, to enhance accomplished successful learner attainment standard, and to support students' self-confident and favorable development. Engagement is also a worthy or a precious form of grasp the progressive method by which students drop out of college (Oqab et al., 2016).

(2012) engagement dimensions are incorporate with the aspects as behavioral (learner's involvement in studying activities such as endeavor, insistence or assertiveness and awareness or attentiveness), emotional (learner's existence of heartiness and attention or concern, reduction of displeasure, feeling bored or dullness and nervousness, or unease, cognitive (learner's use of effective person-organization or planning and advanced or complex study strategies and agentic (learner's positive contribution toward the inflow of the educational acquires).

Teaching style concerning to the educators' behaviors during their teaching in the lecture. It is composed of a teacher's individual behavior and the methods used to transport data to or receive it from the learner (Sharma and Bhaumik, 2013). Effective teaching style is essential for selfdetermination, supervision, monitoring and strong attachment by supply a feeling of the learner guide over science. Perfect teachers make study tasks suitable for the learner's standard of recognition. They also understand the singularity or personality of learners and keep away from the bias to require, "mass production" standards that deal with all students as they the same. The educator noticing can therefore be bring to an end that it draws attention to that the instructor should recognize the attribute of the learners and hence be capable of select a teaching style that allows the learner to determine the behavior help to teach correctly and enjoy more studying (Hesbon and Michael, 2016 \& Esam, 2017).

According to (Chen, $2008 \&$ Tulbure, 2012) teaching styles were categorized into four classification; Authoritarian Teaching Style:"The authoritarian lecturers are accustomed to having authority. They institute that all class rules and specify consequences for rule invasion "Democratic Teaching Style "Even though the democratic lecturers set firm expectations for student behavior and learning, they a tendency to be flexible and respond to different demonds of students. Students are offered extra freedom to make decisions during learning environment "Laissez Faire Teaching Style "On one hand, lecturers who exhibit this teaching style are described as kindness and concern for others because they provide their students with emotional support. 
"Indifferent Teaching Style "The indifferent lecturers center on their individual work. They rarely give extra time with or pay attention to students beyond class time. They offer a few or no emotional support. Furthermore, these lecturers rarely set a rules to dominante students' learning experiences" (Chang, 2010).

The students' perceptions of teaching styles considerd from the important factors affect students' academic engagement other than the teacher's actions and it link to their learning. So, studies have been carried out to examine students'perceptions of teaching styles enable instructors to be orianted of students'perspectives and to recognize the requirement to make readjustments and adaptation in teaching (Chang, 2010).

\section{Significance of the study:}

Teaching styles perceive by student must be known by lecturers. It will guide them to view their role from a various standpoint and realize the significance of reflecting on as adjusting their teaching styles. They can change and enhance their teaching styles to reach the greater level of students' academic excellence. Furthermore, it can assist the experienced lecturer in developing further skills and teach new clinical lecturers and nursing faculty how to maximize effective use of clinical teachers and clinical experiences. In extension; studies regarding teaching style in the universities are minimal conducted, which are related to students' academic engagement. Therefore, the researchers conducted this study.

\section{Aims of the study:}

This study aimed to determine the relationship between students' perceptions of teaching styles and students' academic engagement in South Valley and Assiut Universities.

\section{Research questions:}

1. Is there a difference between students' academic engagement at Nursing Faculties in South Valley and Assiut Universities?

2. What is the main teaching style at Nursing Faculties in South Valley and Assiut Universities?

3. Is there a difference between teaching style at Nursing Faculties in South Valley and Assiut Universities?

4. Is there a relationship between the teaching styles perceived by students and their academic engagement?

5. Is there a relationship between students' academic engagement and their personal characteristics?

\section{Materials and method}

\section{Research design:}

Descriptive correlational research design was used.

\section{Study setting:}

The study was conducted at two Nursing Faculties in South Valley and Assiut Universities at departments of nursing administration, pediatric nursing and obstetrics \& gynecological nursing and reproductive health.

\section{Setting:}

The study was conducted at two Nursing Faculties in South Valley and Assiut Universities at departments of nursing administration, pediatric nursing and obstetrics \& gynecological nursing and reproductive health. 


\section{Study subjects:}

The study subjects included 600 nursing students in the third and fourth academic year, which chosen by a simple random sample. The researchers select the first 100 students (from each department) entered the lecture during data collection. They had studied nursing administration, pediatric nursing and obstetrics \& gynecological nursing and reproductive health course in the second semester of the academic year 2016-2017 were enrolled. 300 nursing students from each university (Assiut $\&$ South Valley) were selected.

\section{Sample size:}

It was calculated by Epi-Info 7.2.0.1 using the sample size equation for estimation of single proportion. The total number of students who were studied in the selected courses during data collection were 834 students in the studied universities. With precision levels 5\% where confidence level is $95 \%$ and $\mathrm{p}<0.05$. The optional sample size was 264 (for each faculty) was obtained for each faculty. The actual sample increased to 300 students to compensate any dropout.

\section{Tools of the study:}

Two tools were used for this study:

Tool one: Students' academic engagement questionnaire: It consisted of two parts as the following:

Part one: Characteristic of studied students as; age, sex, academic grade, university name and attendance rate in the theoretical lectures.

Part two: Students' academic engagement questionnaire which was developed by Shaari, et al. (2014) based on National Survey on Students Engagement (2006) conducted by the College Students Report, Indiana University. It is used to measure students' academic engagement in educational practice. It contains (31) items as; "I always give an opinion in the lecture, have presented the assignments in the lecture, follow the lecturer's instructions and do all the duties, give my full attention to get the duties done, able to learn and complete the work assigned" and so on. All of them focusing on students' behavior which has a high correlation with good learning outcome and practices.

\section{Scoring system:}

The response for each of the items is on a five-point Likert type scale: "strongly disagree," "disagree," "uncertain," "agree," and "strongly agree." The scoring was accordingly from 1 to 5 for each item respectively. The scores of each dimension were summed up and then converted into a percent score. A score of $60 \%$ or higher was considered as "high student academic engagement" and low if less than $60 \%$ and considered low engagement.

Tool two: Teaching styles questionnaire which was developed by Chen (2008). It is used to measure lecturer's teaching styles preferences. It contains 29 items divided into four subscales: democratic (11 items) as; "my lecturer compliments me on my good manners, my lecturer respects my personal privacy", authoritarian (9 items) as; "my lecturer treats students unfairly, I am not allowed to express my personal views freely", laissez-faire (5 items) as; " my lecturer does not discipline students ", and indifferent teaching styles (4 items) as; " my lecturer truly cares about me".

\section{Scoring system:}

The response for each of the items is on a 5-point scale "never", "seldom", "sometimes", "often" and "always", scoring was accordingly from 1 to 5 for each item respectively. For negative items, responses are scored from 5 to 1 for each item 
respectively. A score type is determined by calculating the average value of all responses for the items in the type. Each mean score is associated with a teaching style; a total of four mean scores obtained are compared. The highest score on a type indicates the most frequently perceived teaching style. tools:

\section{Validity and reliability of the study}

The study tools were translated into Arabic language using the translate -retranslate process. Its validity was measured by five experts from the faculty of nursing in the field administration, pediatric and obstetrics \& gynecology nursing departments in South Valley and Assiut Universities. The reliability of the study tools was assessed in a pilot study by measuring their internal Consistency using Cronbach's alpha method. This turned to be $(\alpha=0.89)$ to study tool.

\section{2-Operational design:}

This included the preparatory phase, pilot study, and data collection phase

\section{-Preparatory phase:}

This phase took about three months from December 2016 to Ferbrauary 2017. The researchers spent this time in reviewing the available literature pertinent to the study topic. Additionally, Arabic translation and back translation of the study tool was done, and they were checked by experts for validation.

Pilot study: A pilot study was conducted on a sample of $10 \%$ of students to test the applicability of the tool and test the clarity of the designated questionnaire as well as to estimate the time needed to answer it. It also helped to test the feasibility and suitability of the study settings. Data obtained from the pilot were analyzed and no modifications were done so included from the number of study samble.

\section{Data collection phase:}

- Data were collected from students in the study setting at Faculty of Nursing in Assiut and South Valley Universities. The questionnaire sheet was self-administered filled, purpose and benefits of the study were explained to the participant, one of the researchers was present all the time to clarify any item that needed interpretation to the participant. The researcher informed the participant that their participation is voluntary. Confidentiality and anonymity of subjects were assured by the researchers. The data collection took about 20 minutes for each participant. The whole duration of data collection took about two months from March to April 2017.

\section{3-Administration design:}

To carry out the study; the necessary approval was obtained from the Dean of the faculty of nursing either in Assiut or South Valley Universities. The researchers explained the aim of the study and requesting permission to use the premise for data collection.

\section{Ethical consideration:}

- The study proposal took agreement from the ethical committee of the faculty of nursing at Assiut University.

- An official permission to carry out the study was obtained from the responsible authorities.

-The researchers conducted a meeting with the Dean of Faculty of nursing in South Valley and Assiut Universities to inform them about the objectives of the study and to gain the needed support and cooperation.

-Written consent was obtained from the study participants after explaining the purpose and nature of the study. Also, assure them that their participation would not be 
used against them in any way and they have the right to refuse or to decide to terminate their participation at any time.

\section{4-Statistical design}

Data entry and analysis were done using SPSS version 20 Program statistical software package for social sciences. Data were presented using descriptive statistics in the form of frequencies and percentages. Also, Mean and standard deviations were calculated. Correlation between variables students' academic engagement and teaching styles questionnaire (Pearson correlation) and (t-test) were used statistical significance was considered at $\mathrm{P}$ - value $\leq 0.05$.

\section{Results}

Table (1): Percentage distribution of studied nursing students according to their characteristics:

\begin{tabular}{|c|c|c|c|c|c|c|}
\hline \multirow[t]{2}{*}{ Characteristics } & \multicolumn{2}{|c|}{ Total $(N=600)$} & \multicolumn{2}{|c|}{$\begin{array}{c}\text { Assiut University } \\
(\mathbf{n}=\mathbf{3 0 0})\end{array}$} & \multicolumn{2}{|c|}{$\begin{array}{l}\text { South Valley University } \\
(\mathbf{n}=\mathbf{3 0 0})\end{array}$} \\
\hline & No & $\%$ & No & $\%$ & No & $\%$ \\
\hline \multicolumn{7}{|l|}{ Sex: } \\
\hline - Male & 233 & 38.8 & 81 & 27.0 & 152 & 50.7 \\
\hline - Female & 367 & 61.2 & 219 & 73.0 & 148 & 49.3 \\
\hline \multicolumn{7}{|l|}{ Age/years: } \\
\hline - $<21$ & 81 & 13.5 & 57 & 19.0 & 24 & 8.0 \\
\hline - $21<23$ & 430 & 71.7 & 216 & 72.0 & 214 & 71.3 \\
\hline - $23 \&$ more & 89 & 14.8 & 27 & 9.0 & 62 & 20.7 \\
\hline$($ Mean \pm SD $)$ & & & \multicolumn{2}{|c|}{$21.43 \pm 0.82$} & \multicolumn{2}{|c|}{$21.80 \pm 0.91$} \\
\hline \multicolumn{7}{|l|}{ Academic grades: } \\
\hline - $\quad$ Third grade & 400 & 66.7 & 200 & 66.7 & 200 & 66.7 \\
\hline - Fourth grade & 200 & 33.3 & 100 & 33.3 & 100 & 33.3 \\
\hline \multicolumn{7}{|c|}{ Attendance rate in the theoretical lectures } \\
\hline - $75 \%-100 \%$ & 492 & 82.0 & 234 & 78.0 & 258 & 86.0 \\
\hline - $50 \%-75 \%$ & 89 & 14.8 & 48 & 16.0 & 41 & 13.7 \\
\hline - $25 \%-50 \%$ & 11 & 1.8 & 10 & 3.3 & 1 & 0.3 \\
\hline - $<25 \%$ & 8 & 1.4 & 8 & 2.7 & 0 & 0.0 \\
\hline
\end{tabular}

Table (1): Illustrate percentage distribution of studied nursing students according to their characteristics. The data in this table revealed that $61.2 \%$ of studied nursing students were females and $71.7 \%$ of them their age ranged from 21 to $<23$. It was noticed that two-third $66.7 \%$ of studied nursing students' studying in the third grade. In addition; the attendance rate at $75-100 \%$ was higher $78 \%$ and $86 \%$ in Assiut and South Valley universities respectively. While no one in South Valley University attended less than $25 \%$ compared to $2.7 \%$ in Assiut University. 
Relation between Students' Perception of Teaching Styles and Students' Academic Engagement in South Valley and Assiut Univerities

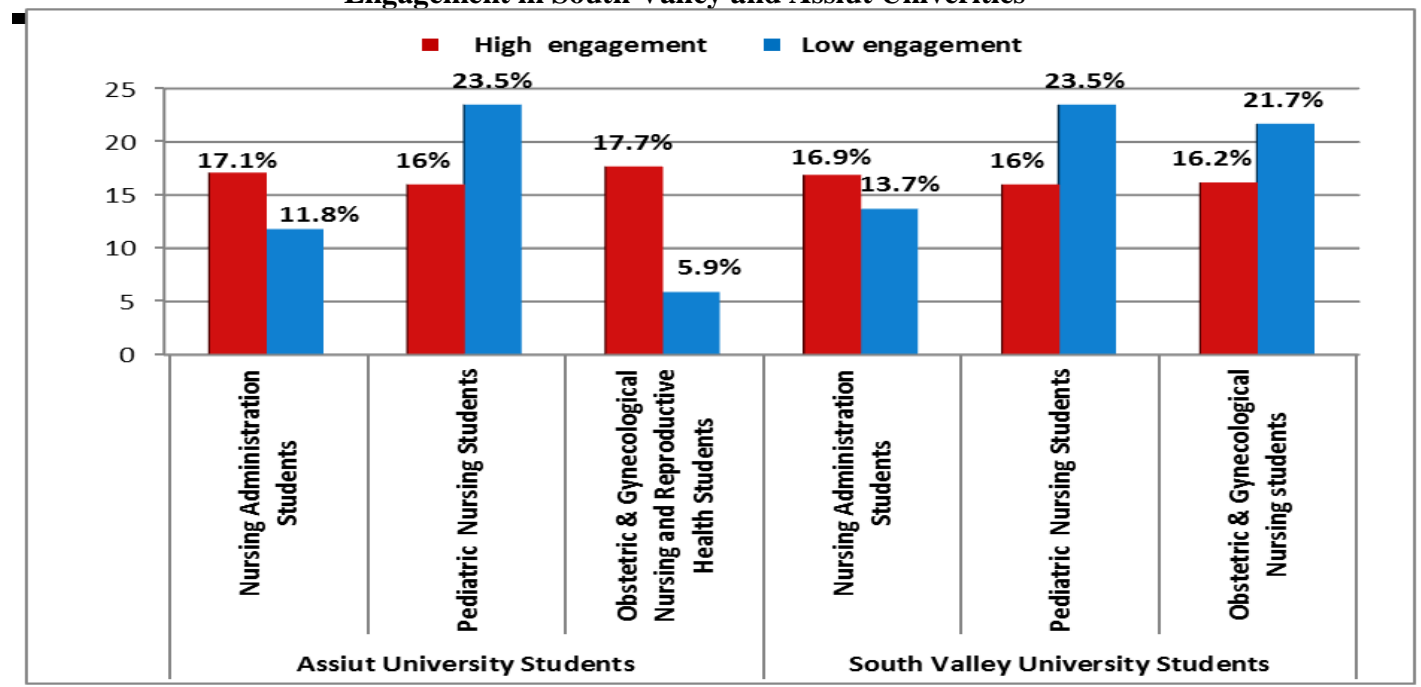

Figure (1): Percentage distribution of studied nursing students' academic engagement.

Figure (1): Illustrate percentage distribution of studied nursing students' academic engagement in the studied departments in Assiut and South-Valley Universities. It was found that higher students' academic engagement $17.7 \%$ was in Assiut University at obstetrics and gynecological nursing department and reproductive health compared to $16.2 \%$ in South-valley University. Followed by nursing administration department in Assiut University was 17.1\% compared to $16.9 \%$ in South-valley University. While pediatric nursing department represented 16\% as regards Assiut and South-valley Universities. The data in the table also indicated that low academic engagement was highest in pediatric department 23.5\% either in Assiut and South-valley Universities.

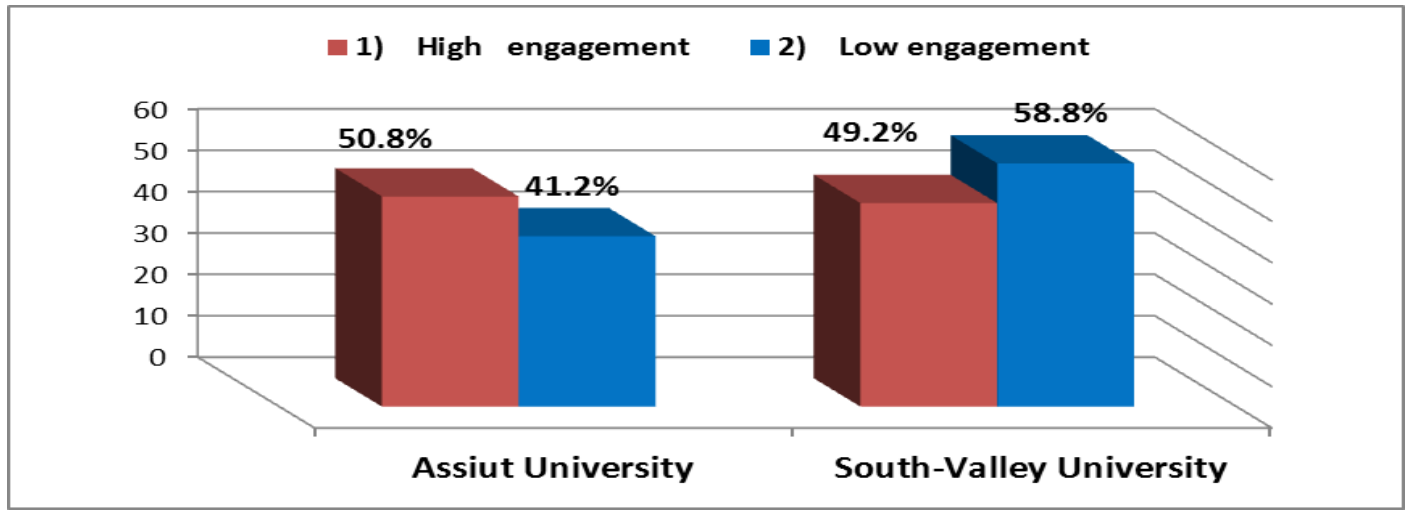

Figure (2): Students' academic engagement in Assiut and South Valley Universities.

Figure (2): Illustrates the students' academic engagement in Assiut and South Valley Universities. It was found that students' academic engagement in Assiut University was higher $50.8 \%$ than in South-Valley University $49.2 \%$. 
Table (2): Mean score distribution of studied nursing students concerning perception of lecturers' teaching styles in the studied departments $(\mathrm{N}=600)$ :

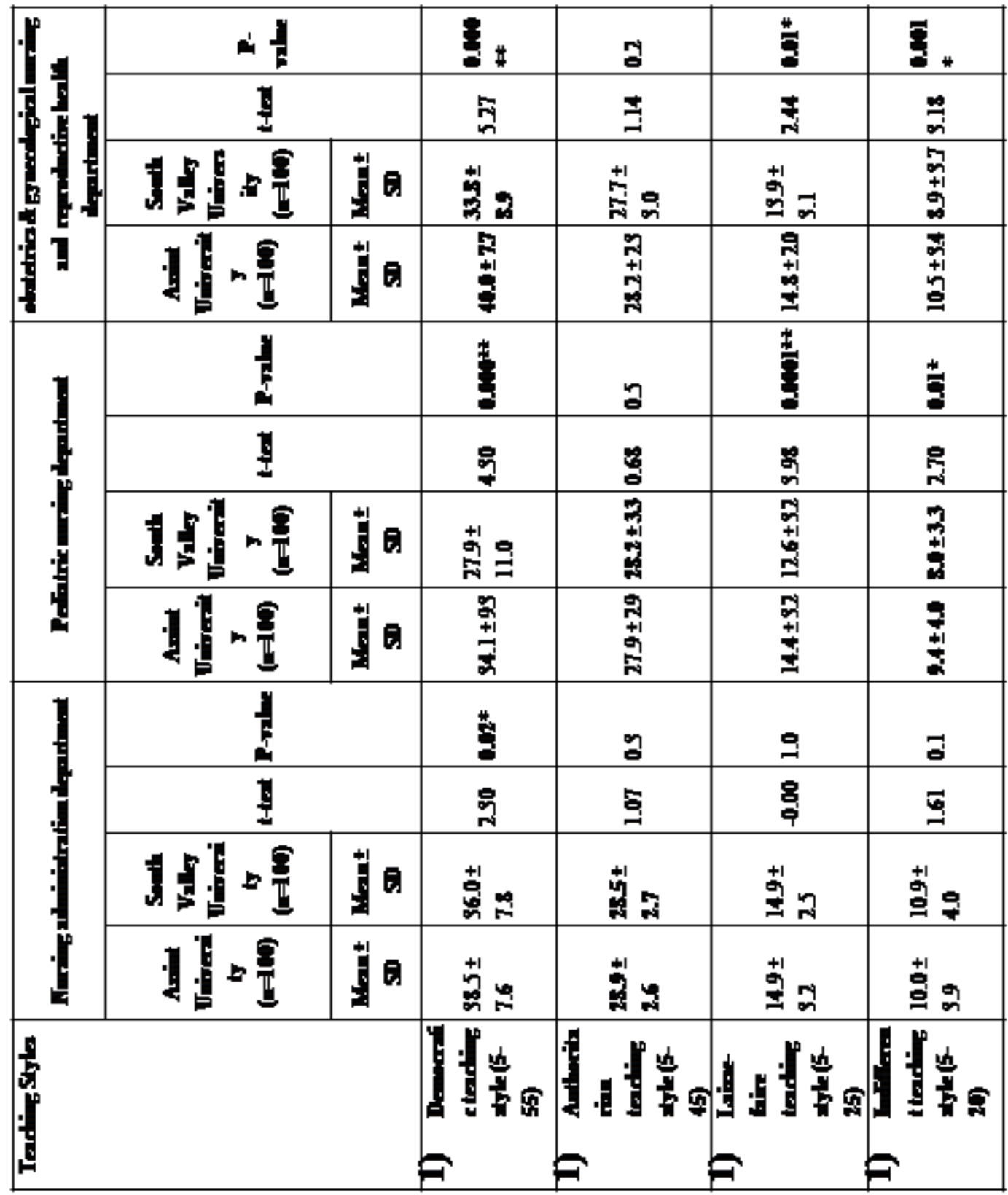

t-test significance at $\mathrm{p}=<0.05$.

Table (2): Reveals the Mean score of studied nursing students concerning the perception of lecturers' teaching styles in the studied departments. The data in this table found that democratic teaching style represented the highest mean score in obstetrics \& gynecological nursing and 
reproductive health department in Assiut University (40.0 \pm 7.7) compared to $(33.8 \pm$ 8.9) with a statistically significant difference in South Valley University. While the low Mean score was related to indifferent teaching style in pediatric nursing department in South Valley University $(\mathbf{8 . 0} \pm \mathbf{3 . 3})$ compared to $(9.4 \pm \mathbf{4 . 0})$ in Assiut University with a statistically significant difference.

Table (3): Correlation between studied nursing students' academic engagement and their perception of lecturers' teaching styles in the studied departments $(\mathrm{N}=600)$ :

\begin{tabular}{|c|c|c|c|c|c|c|c|c|c|c|c|c|}
\hline \multirow{4}{*}{ Teaching Styles } & \multicolumn{12}{|c|}{ Students' Academic Engagement } \\
\hline & \multicolumn{4}{|c|}{$\begin{array}{c}\text { Nursing administration } \\
\text { department }\end{array}$} & \multicolumn{4}{|c|}{ Pediatric nursing department } & \multicolumn{4}{|c|}{$\begin{array}{c}\text { Obstetrics and } \\
\text { gynecological nursing } \\
\text { department }\end{array}$} \\
\hline & \multicolumn{2}{|c|}{$\begin{array}{c}\text { Assiut } \\
\text { University } \\
(\mathbf{n}=\mathbf{1 0 0})\end{array}$} & \multicolumn{2}{|c|}{$\begin{array}{c}\text { South } \\
\text { Valley } \\
\text { University } \\
(\mathbf{n}=100)\end{array}$} & \multicolumn{2}{|c|}{$\begin{array}{c}\text { Assiut } \\
\text { University } \\
(\mathbf{n}=100)\end{array}$} & \multicolumn{2}{|c|}{$\begin{array}{l}\text { South Valley } \\
\text { University } \\
(\mathbf{n}=\mathbf{1 0 0})\end{array}$} & \multicolumn{2}{|c|}{$\begin{array}{c}\text { Assiut } \\
\text { University } \\
(\mathbf{n}=100)\end{array}$} & \multicolumn{2}{|c|}{$\begin{array}{c}\text { South Valley } \\
\text { University } \\
(n=100)\end{array}$} \\
\hline & $\mathbf{R}$ & $\mathbf{P}$ & $\mathbf{r}$ & $\mathbf{P}$ & $\mathbf{R}$ & $\mathbf{P}$ & $\mathbf{r}$ & $\mathbf{P}$ & $\mathbf{r}$ & $\mathbf{P}$ & $\mathbf{r}$ & $\mathbf{P}$ \\
\hline $\begin{array}{l}\text { 1. Democratic } \\
\text { teaching style }\end{array}$ & 0.01 & 0.9 & 0.1 & 0.4 & 0.4 & $\mathbf{0 . 0 0 0} * *$ & 0.25 & 0.01* & 0.13 & 0.2 & 0.2 & 0.01* \\
\hline $\begin{array}{ll}\text { 2. } & \text { Authoritarian } \\
& \text { teaching style }\end{array}$ & $\begin{array}{c}- \\
0.01\end{array}$ & 0.89 & 0.2 & 0.04* & 0.13 & 0.2 & 0.3 & $\mathbf{0 . 0 0 3}^{*}$ & 0.2 & 0.1 & 0.05 & 0.6 \\
\hline $\begin{array}{ll}\text { 3. } & \text { Laizse-faire } \\
& \text { teaching style }\end{array}$ & 0.14 & 0.2 & 0.1 & 0.5 & 0.13 & 0.2 & 0.2 & $\mathbf{0 . 0 1} *$ & 0.2 & 0.06 & 0.13 & 0.2 \\
\hline $\begin{array}{ll}\text { 4. } & \text { Indifferent } \\
& \text { teaching style }\end{array}$ & 0.1 & 0.5 & $\overline{-}$ & 0.15 & 0.01 & 0.9 & 0.1 & 0.3 & 0.04 & 0.7 & 0.1 & 0.3 \\
\hline
\end{tabular}

Table (3): Provides an insight about correlation between studied nursing students' academic engagement and their perception of lecturers' teaching styles in the studied departments. The data in this table indicated that there were highly positive statistically significant correlation between democratic teaching style and students' academic engagement in pediatric nursing department in Assiut and South Valley Universities and in obstetrics and gynecological nursing department in South Valley University with $\left(\mathrm{p}=0.000^{* *}, \mathrm{p}=0.01 *, \mathrm{p}=0.01\right.$ *and $\mathrm{r}=0.4, \mathrm{r}=0.25, \mathrm{r}=$ 0.2 ) respectively. In addition; there was positive statistically significant correlation between authoritarian teaching style and students' academic engagement in nursing administration department and in pediatric nursing department in South Valley University with $\left(\mathrm{p}=0.04^{*}\right.$, $\mathrm{p}=0.003^{*}$ and $\mathrm{r}=0.2, \mathrm{r}=0.3$ ) respectively. Also, there was a positive statistically significant correlation between Laizse-faire teaching style and students' academic engagement in pediatric nursing department in South Valley University with $(\mathrm{p}=0.01 *$, and $\mathrm{r}=0.2)$. 
Table (4): Relation between students' academic engagement and their characteristics $(\mathrm{N}=600)$ :

\begin{tabular}{|c|c|c|c|c|c|c|c|c|c|c|c|c|}
\hline \multirow{4}{*}{ Characteristics } & \multicolumn{12}{|c|}{$\begin{array}{ll}\text { Students' Academic Engagement } \\
\end{array}$} \\
\hline & \multicolumn{4}{|c|}{$\begin{array}{c}\text { Nursing administration } \\
\text { students }\end{array}$} & \multicolumn{4}{|c|}{$\begin{array}{c}\text { Pediatric nursing } \\
\text { students }\end{array}$} & \multicolumn{4}{|c|}{$\begin{array}{c}\text { Obstetrics and } \\
\text { gynecological nursing } \\
\text { students } \\
\end{array}$} \\
\hline & \multicolumn{2}{|c|}{$\begin{array}{c}\text { Assiut } \\
\text { University } \\
(\mathbf{n}=\mathbf{1 0 0})\end{array}$} & \multicolumn{2}{|c|}{$\begin{array}{c}\text { South } \\
\text { Valley } \\
\text { University } \\
(\mathbf{n}=\mathbf{1 0 0})\end{array}$} & \multicolumn{2}{|c|}{$\begin{array}{c}\text { Assiut } \\
\text { University } \\
(\mathbf{n}=\mathbf{1 0 0})\end{array}$} & \multicolumn{2}{|c|}{$\begin{array}{c}\text { South } \\
\text { Valley } \\
\text { University } \\
(\mathbf{n}=100)\end{array}$} & \multicolumn{2}{|c|}{$\begin{array}{c}\text { Assiut } \\
\text { University } \\
(n=100)\end{array}$} & \multicolumn{2}{|c|}{$\begin{array}{c}\text { South } \\
\text { Valley } \\
\text { University } \\
(\mathbf{n}=100)\end{array}$} \\
\hline & $\mathbf{X}^{2}$ & $\mathbf{P}$ & $\mathbf{X}^{2}$ & $\mathbf{P}$ & $\mathbf{X}^{2}$ & $\mathbf{P}$ & $\mathbf{X}^{2}$ & $\mathbf{P}$ & $\mathbf{X}^{2}$ & $\mathbf{P}$ & $\mathrm{X}^{2}$ & $\mathbf{P}$ \\
\hline - Sex & 0.01 & 0.7 & 0.1 & 0.5 & 2.7 & 0.1 & 0.3 & 0.4 & 0.1 & 0.6 & 6.1 & $0.01 *$ \\
\hline - Age & 1.7 & 0.4 & 1.3 & 0.7 & 0.6 & 0.9 & 1.6 & 0.8 & 0.4 & 0.9 & 3.7 & 0.6 \\
\hline $\begin{array}{l}\text { - Attendance } \\
\text { rate }\end{array}$ & 14.9 & 0.2 & 18.6 & 0.3 & 36.3 & 0.001* & 14.0 & 0.4 & 14.9 & 0.7 & 11.8 & 0.4 \\
\hline
\end{tabular}

Table (4): Depicts relation between students' academic engagement and their characteristics. The data in this table pointed that there was a statistically significant difference between sex and student academic engagement with obstetrics and gynecological nursing students in South Valley University $(\mathbf{p}=\mathbf{0 . 0 1}$ *). Also, there were a statistically significant difference between attendance rate and students' academic engagement with pediatric nursing students Assiut University (p=0.001). 
Relation between Students' Perception of Teaching Styles and Students' Academic Engagement in South Valley and Assiut Univerities

Table (5): Relationship between students' perception of teaching styles and their characteristics $(\mathrm{N}=600)$ :

\begin{tabular}{|c|c|c|c|c|c|c|c|c|c|c|c|c|}
\hline \multirow{4}{*}{ Characteristics } & \multicolumn{12}{|c|}{ Students' Perception of Teaching Style } \\
\hline & \multicolumn{4}{|c|}{$\begin{array}{l}\text { Nursing administration } \\
\text { students }\end{array}$} & \multicolumn{4}{|c|}{ Pediatric nursing students } & \multicolumn{4}{|c|}{$\begin{array}{c}\text { Obstetrics and } \\
\text { gynecological nursing } \\
\text { students }\end{array}$} \\
\hline & \multicolumn{2}{|c|}{$\begin{array}{c}\text { Assiut } \\
\text { University } \\
(\mathbf{n}=\mathbf{1 0 0})\end{array}$} & \multicolumn{2}{|c|}{$\begin{array}{c}\text { South Valley } \\
\text { University } \\
(\mathbf{n}=100)\end{array}$} & \multicolumn{2}{|c|}{$\begin{array}{c}\text { Assiut } \\
\text { University } \\
(\mathbf{n}=100)\end{array}$} & \multicolumn{2}{|c|}{$\begin{array}{c}\text { South Valley } \\
\text { University } \\
(\mathbf{n}=\mathbf{1 0 0})\end{array}$} & \multicolumn{2}{|c|}{$\begin{array}{c}\text { Assiut } \\
\text { University } \\
(\mathbf{n}=\mathbf{1 0 0})\end{array}$} & \multicolumn{2}{|c|}{$\begin{array}{c}\text { South Valley } \\
\text { University } \\
(\mathbf{n}=100)\end{array}$} \\
\hline & $\mathbf{X}^{2}$ & $\mathbf{P}$ & $\mathbf{X}^{2}$ & $\mathbf{P}$ & $\mathbf{X}^{2}$ & $\mathbf{P}$ & $\mathbf{X}^{2}$ & $\mathbf{P}$ & $\mathbf{X}^{2}$ & $\mathbf{P}$ & $\mathbf{X}^{2}$ & $\mathbf{P}$ \\
\hline \multicolumn{13}{|l|}{ Sex: } \\
\hline $\begin{array}{ll}\text { 1. } & \text { Democratic } \\
\text { teaching } \\
\text { styles }\end{array}$ & 26.7 & 0.7 & 28.7 & 0.5 & 35.5 & 0.4 & 38.0 & 0.3 & 28.0 & 0.5 & 33.8 & 0.4 \\
\hline $\begin{array}{ll}\text { 2. } & \text { Authoritaria } \\
& \text { n teaching } \\
\text { styles }\end{array}$ & 10.8 & 0.5 & 9.1 & 0.7 & 16.1 & 0.3 & 11.8 & 0.7 & 8.9 & 0.7 & 20.9 & 0.1 \\
\hline $\begin{array}{ll}3 . & \begin{array}{l}\text { laissez-fair } \\
\text { teaching } \\
\text { styles }\end{array} \\
\end{array}$ & 14.5 & 0.5 & 10.3 & 0.5 & 15.2 & 0.5 & 12.4 & 0.5 & 9.2 & 0.5 & 14.6 & 0.3 \\
\hline $\begin{array}{ll}\text { 4. } & \begin{array}{l}\text { Indifferent } \\
\text { teaching } \\
\text { styles }\end{array} \\
\end{array}$ & 9.1 & 0.9 & 12.6 & 0.7 & 11.0 & 0.7 & 37.3 & $0.001 *$ & 18.7 & 0.2 & 21.1 & 0.1 \\
\hline \multicolumn{13}{|l|}{ Age: } \\
\hline $\begin{array}{l}\text { 1. } \begin{array}{l}\text { Democratic } \\
\text { teaching } \\
\text { styles }\end{array} \\
\end{array}$ & 62.5 & 0.4 & 86.8 & 0.6 & 68.8 & 0.5 & 1.6 & 0.1 & 95.4 & 0.2 & 1.6 & $0.02 *$ \\
\hline $\begin{array}{ll}\text { 2. } & \text { Authoritaria } \\
& n \text { teaching } \\
\text { styles }\end{array}$ & 30.0 & 0.2 & 29.9 & 0.7 & 25.0 & 0.6 & 39.0 & 1.0 & 27.8 & 0.8 & 50.4 & 0.5 \\
\hline $\begin{array}{l}\text { 3. laissez-fair } \\
\text { teaching } \\
\text { styles }\end{array}$ & 29.1 & 0.5 & 26.2 & 0.8 & 35.1 & 0.3 & 52.2 & 0.5 & 33.7 & 0.3 & 87.4 & $0.002 *$ \\
\hline $\begin{array}{ll}4 . & \text { Indifferent } \\
& \text { teaching } \\
\text { styles }\end{array}$ & 34.4 & 0.3 & 53.1 & 0.3 & 28.2 & 0.5 & 61.7 & 0.1 & 56.9 & 0.1 & 65.2 & 0.3 \\
\hline \multicolumn{13}{|l|}{ Attendance rate: } \\
\hline $\begin{array}{ll}\text { 1. } & \begin{array}{l}\text { Democratic } \\
\text { teaching } \\
\text { styles }\end{array} \\
\end{array}$ & 3.0 & 0.9 & 6.1 & $0.002 *$ & 6.5 & $0.05^{*}$ & 4.9 & 0.3 & 5.7 & 0.1 & 3.3 & 0.7 \\
\hline $\begin{array}{ll}\text { 2. } & \text { Authoritaria } \\
\mathrm{n} \text { teaching } \\
\text { styles }\end{array}$ & 1.3 & 0.6 & 1.4 & 1.0 & 2.4 & 0.4 & 2.4 & 0.1 & 1.8 & 1.0 & 1.8 & $0.02 *$ \\
\hline $\begin{array}{ll}\text { 3. } & \text { laissez-fair } \\
\text { teaching } \\
\text { styles }\end{array}$ & 1.4 & 0.9 & 2.0 & 0.2 & 3.3 & $0.01 *$ & 1.9 & 0.4 & 2.2 & $0.04 *$ & 1.5 & 0.4 \\
\hline $\begin{array}{l}\text { 4. } \begin{array}{l}\text { Indifferent } \\
\text { teaching } \\
\text { styles }\end{array} \\
\end{array}$ & 1.6 & 0.6 & 2.5 & 0.8 & 2.7 & 0.2 & 1.8 & 0.3 & 3.0 & 0.2 & 1.3 & 0.9 \\
\hline
\end{tabular}


Table (5): Indicates the relationship between students' perception of teaching styles and their characteristics. The data in this table revealed that there was a statistically significant difference between indifferent teaching styles and sex in pediatric nursing students at South Valley University with $(\mathbf{p}=\mathbf{0 . 0 1} *)$. The data in table also demonstrated that there was a statistically significant difference between democratic, laissez-faire teaching styles and age in obstetrics and gynecological nursing students in South Valley Universities with $(\mathbf{p}=\mathbf{0 . 0 2} * \mathbf{p}=\mathbf{0 . 0 0 2} *)$ respectively. In addition there were statistically significant differences between democratic teaching styles and attendance rate in nursing administration in Assiut University and pediatric nursing students at South Valley University with $(\mathbf{p}=\mathbf{0 . 0 0 2} * \mathbf{p}=\mathbf{0 . 0 5} *$. Respectively, between authoritarian teaching styles and attendance rate in obstetrics and gynecological nursing students at South Valley University with $(\mathbf{p = 0 . 0 2 *})$ and between laissez-fair teaching styles in and Obstetrics and gynecological and pediatric nursing students and attendance rate in Assiut University with $(\mathbf{p}=\mathbf{0 . 0 1} * \mathbf{p}=\mathbf{0 . 0 4} *)$ respectively.

\section{Discussion}

Student academic engagement is at most concerning to teachers' styles. So, lecturers should use various teaching styles and vary in how they manage their classes, how they react with students, and how they view their role as educators because an effective teacher is equivalent to advancing knowledge in one academic year (Hudzik, 2011).

This study aimed to determine the relationship between students' perceptions of teaching styles and students' academic engagement in South Valley and Assiut Universities. The finding of the present study revealed that, higher students' academic engagement was in the Obstetrics \& Gynecological Nursing and reproductive health department and then nursing administration department in Assiut and administration department follow by the Obstetrics \& Gynecological Nursing department in South Valley Universities (Table 1). These might due to serious supervision and control, effective discipline and a healthy learning environment in two nursing department and lecturers' emphasis for engaging their students in a diversity of activities. In harmony with these study findings, Horstmanshof \& Zimitat, (2011) who conducted the research on future time orientation predicts academic engagement among first year university students. the researchers established that students who are active in classroom activities with positive students' participation and improving their theoretical engagement.

The results of the current study show that, lowest students' academic engagement was in pediatric nursing department in Assiut and South Valley Universities (Fig.1). This might be justified by the reality that students not adapt to pediatric nursing department environment may be concerning to that the student not fit with the time \& place of lectures set under the rules of the educational institution and also Inflation or expansion in the size of the curriculum depend on student's opinion. In contrast with this finding Joye1 \& Wilson (2015) who conducted study titled professor age and gender affect student perceptions and grades and asserted that the function of teaching is to make or manufacture effective teaching. Therefore, a good lesson should involve teachers' skills; ensure the teaching methods suit with students' learning objectives and learning style. This is because learning is the activity of intellectual and spiritual to the students so that lessons could become organized to bring change in students' attitude. Therefore, organized approach should be achievement by lecturers in the growth or illustrate knowledge by using suitable methods to produce an efficient educational environment through the lectures to improve student's engagement. 
Related to the student academic engagement in Assiut and South Valley Universities, the finding of the current study manifested, that student academic engagement in Assiut University higher than South Valley University (Fig.2).This might due to that the students comfortable with the culture and has feeling of involvement and commitment to Assiut University. These finding assured by Wilson \& Ryan, (2013) they stated that student's share in academic will influence the student's psychosocial development (engagement) throughout his/her college life.

As regard to students' perception of lecturers' teaching styles in the studied departments in Assiut and South valley Universities, the finding of the current study demonstrated that dominant style were democratic teaching style and it had the highest mean score for the three studied departments except for pediatric nursing department in South Valley university authoritarian teaching style had high score (Table 2) these might due to that the lecturers in pediatric nursing department not involve students in learning activities and don't provide interpretation to decision making that affect their learning, In contrast with these finding Chang, (2010) who conducted research students' on perceptions of teaching styles and use of learning strategies in Taiwanese and concluded that according to students' perceptions, the indifference teaching style is the predominant and majority of the students felt that their teachers paid too a great concern to their have profession and did not have close relationships with learners.

Moreover (table 2) detected that the democratic teaching style among students significantly differences in three studied departments in Assiut and South Valley Universities. Also, there were statistically significant differences between students related to laissez-fair and indifferent teaching styles in Obstetrics \& Gynecological Nursing and reproductive health and pediatrics nursing departments in the Assiut and South Valley Universities. These justified by the fact that the purpose and design of courses, norms of learning, and academic discipline in Assiut University differ from the South Valley University.

The study supports previous finding of, Michelle \& Cardwell, (2011) who established that the teacher's ethnicity, gender, seniority and time also player reflect on lecturer's educational styles and influencing their instruction. Also the finding is congruent with Heenaye, Gobin and Khan (2012) mentioned that teachers' teaching style was influenced by the ideology and beliefs of students and knowledge.

The current study results state that the democratic learning style and students' academic engagement are a strongly correlated in the pediatric nursing department in Assiut and South Valley Universities and in obstetrics and gynecological nursing and reproductive health department in South Valley University. Also, this study declared that a strong positive significant relation between authoritarian teaching style and students' academic engagement in administration and pediatric nursing departments in South Valley University. Moreover the current study also depicted that the laissez-fair teaching styles and students' academic engagement were statistically correlated in the pediatric nursing department in South Valley University Table (3).

This finding consistent with Esam, (2017) who asserted that students who perceived authoritarian or a democratic teaching style with more achievement than students perceived a laissez-faire or an indifferent teaching style. Also, in concurrent with the actual study, Shaari, (2014) who concluded that a significant but modest relationship between lecturers' teaching style with the student's academic engagement. In relation, Lujan, Cox and DiCarlo, (2011) they stated that behaviouristic learning is learning that include accommodation and 
imitation. This study supports the view that students' attitudes to share or participate in the process of teaching and learning in the lecture is greatly affected by individual model of teaching style.

Based on the outcomes of the actual study it was found that the students' sex were statistically significantly with students' academic engagement in Obstetrics \& Gynecological Nursing and reproductive health in South Valley University (Table 4), In agreement with these study findings Chen, (2008). Who found that girls, compared with boys, have statistical evidence that female students with higher levels of engagement and are pointed out by teachers as having best academic performance. In contrast Lam et al., (2012) they reported that there were a positive association between student engagement and academic achievement regardless of race, gender, and socioeconomical level.

Also, this study declared that there is significant difference among attendance rate and students' academic engagement in pediatric nursing department due to that male students less attendance rate than female students based on investigate rate between both sex and may be related to the nature of male less commitment than female or afternoon lectures less attendance and understanding than morning time lecturers, In this context Lockenhof et al., (2014) stated that students who are behaviorally involved would typically react with behavioral standared, such as attendance and involvement, and would demonstrate the loss or lack of badly behaved or negative behavior. In the same line with Lukkarinena, Koivukangasa and Seppola, (2016) they found that student academic engagement improves when challenging goals are presented in the collage environment. Wherase Arulampalam et al., 2012 \& Andrietti, (2014) stated that students who perform well are those who record more lecture attendance hours (a proxy for motivation) despite having all learning materials online. Moreover, D'Addazio \& Andrietti, (2012) founded that attendance had a positive and significant impact on academic performance.

\section{Although, Andrietti, Addazio and}

Velasco Gomez, (2011) stated that Students' class attendance and engagement plays an important role in today's higher education. Various preceding studies shown that the attendance of students in lectures is an significant and serious predictor of theoretical outcomes, students who present somemore classes learn higher final grades. In contrast (Hughes \& Chen, (2011). Who showed no correlationship among class attendance and student performance was identified after adapt for control variables that included gender and age. In addition other study refer to the regular presence and participation of students in lectures having greater influnce on examination performance Ryan \& Wilson, (2014).

Additionally, the actual study indicated that significant relation between students perceptions of indifferent teaching styles and sex in pediatric nursing department in South Valley University (Table 5). This is congruence with Lackenhoff et al., (2014) who concluded that there were statistically differences in the perception of traditional and modern teaching styles between both sex of student. In contrast Chang, (2010) who establish that there no gender variation in students 'preferred and recognize teaching styles.

Moreover, the study findings indicated that were significant relation between student's perceptions of democratic, laissez-fair teaching styles and age in obstetrics \& gynecological nursing and reproductive health department in South Valley University. This is in the same line with the study finding of Ebert, Steffens, \& Kroth, (2014) have found that cultural norms as gender, age, and attraction of their 
professors positively affect perception of student. For example, female are anticipated to be kind, acceptable,open-minded. In relation Lackenhoff, (2014) they support the thought that teachers age negatively influence perceptions of student in a personal appeal.

Lastly the current results depicted that were significant relation between democratic teaching styles and attendance rate in nursing administration department in South Valley University and Pediatric nursing department in Assiut University, between authoritarian teaching styles and obstetrics \& gynecological nursing and reproductive health department in South Valley University and between laissez-fair teaching styles in Pediatric and obstetrics \& gynecological nursing and reproductive health department in Assiut University, In contrast with these finding of $\mathbf{L i}$, Chen, and Tsai, (2008) founded that numerous variables that have impact in student's perception and evaluations of their teachers such as, a student's previously attension in the subject issue, predictable grade in the course \& purpose for grasping the course build within the student and are outside of an instructor's control.

\section{Conclusion:}

The following conclusions were drawn based on the results of the present study and research questions:

- The students' academic engagement in Assiut University higher than in South Valley University. The most dominant teaching styles at South Valley and Assiut Universities were democratic teaching style followed by authoritarian teaching style. There was a highly positive statistically significant correlation between a student's perception of teaching styles and their academic engagement. There was statistically significant difference between students' academic engagement and sex and attendance rate. The research also revealed that there were statistically significant difference between student's perception of teaching styles and their personal characteristics.

\section{Recommendations:}

Based on the findings of the present study, the following recommendations are proposed:

1. It is hoped that university students could recognize and understand that academic engagement is one of the momentums towards success in their studies.

2. The university students need to identify their style of academic engagement and suit themselves with lecturers' teaching styles in the classroom.

3. Nursing departments should provide a sense of belonging for all students, in particular, girls and unsocial students which can enhance their academic engagement levels.

4. The university and the lecturers should provide a positive teaching and learning environment which is up to date because it can form a conducive and suitable environment for students' academic engagement.

5. Future research should investigate actual teaching styles used by teachers or teaching styles perceived by teachers' supervisors, not just students' perceptions.

\section{References:}

Abdull S., Nurahimah M., Izam M., Rafisah $\mathrm{H}$ and Nur Fatirah M. (2014): The Relationship between Lecturers Teaching Style and Student's Academic Engagement, International Conference on 
Knowledge-Innovation-

Synergy in Language Research and Practice, University Kebangsaan Malaysia, Social and Behavioral Sciences $11810-20$.

Al-Hendawi M. (2012): Academic Engagement of Students with Emotional and Behavioral Disorders: Existing Research, Issues, and Future.

Andrietti V. (2014). Does Lecture Attendance Affect Academic Performance? Panel Data evidence for Introductory Macroeconomics. International Review of Economics Education 15: 1-16.

Andrietti V., D'Addazio R and Velasco G. (2011). Class attendance and economic performance among Spanish economics students. Mimeo, Universidad Carlos III de Madrid.

Arulampalam W., Naylor R., and Smith J. (2012). Am I missing something? The effects of absence from class on student performance. Economics of Education Review 31(4): 363-375.

Casuso-H., Antonio I., Noelia M.s, Francisco J. and Manuel V. (2013): The Association between Academic Engagement and Achievement in Health Sciences Students, BMC Medical Education, 313:33- 0.1186/1472-692013-33

Chang Y. (2010): Students' Perceptions of Teaching Styles and Use of Learning Strategies University of Tennessee, Tennessee Research and Creative Exchange, Masters Theses Graduate Schoo.

http://trace.tennessee.edu/utk_gradthes/78 $\underline{21}$.

Chen, Y. (2008): An Investigation of the Relationships between Teaching Style and Studies Achievement in IMiaoli Jianguo Junior High School. (Unpublished master's thesis). Hsuan Chuang University, Miaoli, Taiwan.

D’Addazio R. \& Andrietti V. (2012): Does Class Attendance Affect Academic Performance? Evidence from D’Annunzio University, January 30, 2012

Ebert I., Steffans M., and Kroth A. (2014). Warm, but Maybe not to Competent?Contemporary implicit stereotypes of Women and Men in Germany. Sex Roles, 70(9-10), 359-375. doi: 10.1007/s11199014-0369-5Bentham,

DOI: 10.2174/1874210601711010109

Esam O. (2017): Perceptions of Teaching Methods for Preclinical Oral Surgery: A Comparison with Learning Styles, The Open Dentistry Journal, 11, 109-119 109, 1874-2106/17 2017.

Fredricks, J.A. \& McColskey, S.L. (2012). The Measurement of Student Engagement: A comparative Analysis of Various Methods and Student Self-Report Instruments. In: In S.L. Christenson, A.L. Reschly, \& C. Wylie (Eds.), Handbook of research on student engagement (Pp. 763782). New York, NY: Springer.

Heenaye M, Gobin BA and Khan N, (2012): Analysis of Felder-Solomon Index of Learning Styles of Students from Management and Engineering at the University of Mauritius. J Edu Voc Res; 3(8): 244-9.

Hesbon O. \& Michael N. (2016): The Teaching Methods Used in Universities in Rwanda and their Effect on the Students' Academic Performance, World Journal of Educational Research, Vol. 3, No. 5, pp. 1-18, E-ISSN: 2334 -3176.

Horstmanshof L., \& Zimitat, C. (2011): Future time orientation predicts academic 
engagement among first year university students. British Journal of Educational Psychology, 77(3), 703-718.

Hudzik, J. (2011). Comprehensive internationalization: From concept to action. Washington, DC: NAFSA: Association of International Educators.

Hughes, J.N. \& Chen, Q. (2011). 'Reciprocal effects of student-teacher and studentpeer relatedness: Effects on academic self efficacy'. Journal of Applied Developmental Psychology, 32 (5), 278287.

Joye1 S. and Wilson J. (2015): Professor Age and Gender Affect Student Perceptions and Grades, Journal of the Scholarship of Teaching and Learning, Vol. 15, No. 4, August, 2015, pp.126138. doi: 10.14434/josotl.v15i4.13466

Lackenhof C., Chan W., McCrae R., De Fruyt F., Jussim L. and De Bolle M.. (2014). Gender Stereotypes of Personality: Universal and Accurate? Journal of Cross-Cultural Psychology, 45(5), 675-694. doi: $10.1177 / 0022022113520075$.

Lam, S., Jimerson, S., Kikas, E., Cefai,C., Veiga F., Nelson, B., Hatzichristou, C., Polychroni F., Basnett J., Duck R., Farrell P., Liu Y., Negovan V., Shin H., Stanculescu E., Wong B., YangH. and Zollneritsch, J. (2012). Do Girls and Boys Perceive Themselves as Equally Engaged in School? The Results of an International Study From 12 Countries.Journal of School Psychology,50, 77-94.

Li Y., Chen P. and Tsai, S. (2008): A Comparison of the Learning Styles among Different Nursing Programs in Taiwan: Implications for Nursing Education. Nurse Education Today, 28, pp. 70-76.
Lujan H., Cox J., and DiCarlo S. (2011) Does Sex (Female Versus Male) Influence the Impact of Class Attendance on Examination Performance? Advances in Physiology Education, 35, 416-420.

Lukkarinena A., Koivukangasa P. and Seppäläa T. (2016): Relationship between Class Attendance and Student Performance, $2^{\text {nd }}$ ed., International Conference on Higher Education Advances, HEAd'16, 21-23 June 2016,València, Spain, Aalto University School of Business, Runeberginkatu 1416, 00100 Helsinki, Finland.

Michelle E. \& Cardwell (2011): Patterns of Relationships Between Teacher Engagement and Student Engagement, http://fisherpub.sjfc.edu/education_etd/49 and is brought to you for free and open access by Fisher Digital Publications at St. John Fisher College

National survey of student engagement (2006). The College Student Report. Bloomington, IN: Indiana University Center for Postsecondary Research and Planning. Cited in Shaari et al., (2014). The Relationship between Lecturers' Teaching Style And Students' Academic Engagement, University Utara Malaysia, Malaysia. Social and Behavioral Sciences 118 (2014) $10-20$.

Oqab A., Huy P,. Phan I and Bing H. (2016): Academic Engagement: An Overview of Its Definitions, Dimensions, and Major Conceptualizations, International Education Studies; Vol. 9, No. 12; ISSN 1913-9020 E-ISSN 1913-9039 Published by Canadian Center of Science and Education 41, University of New England, Armidale, NSW, Australia.

Ryan R. \& Wilson J. (2014): ProfessorStudent Rapport Scale: Psychometric properties of the brief version. Journal of the Scholarship of Teaching and Learning, 14(3), 64-74. 
Shaari A., Yusoff N., Ghazali I., Osman R. and Dzahir N. (2014): The Relationship between Lecturers' Teaching Style and Students' Academic Engagement, Universiti Utara Malaysia, Malaysia., Procedia - Social and Behavioral Sciences 118 (2014) $10-20$.

Sharma \& Bhaumik. (2013): Academic Engagement: An Overview of Its Definitions, Dimensions, and Major Conceptualisations, Available from: https://www.researchgate.net/publication/ 311085675_Academic_Engagement_An_ Overview_of_Its_Definitions_Dimension

\section{s_and_Major_Conceptualisations} [accessed May 30, 2017].

Tulbure C. (2012): Learning Styles, Teaching Strategies and Academic Achievement in Higher Education: A cross-sectional Investigation. Procedia-Social and Behavioral Sciences; 33:398-402. Retrieved: doi:10.1016/j.sbspro.2012.01.151

Wilson, J. H., \& Ryan, R. G. (2013). StudentTeacher Rapport Scale: Six Items Predict Student Outcomes. Teaching of Psychology, 40, 130-133. 